\title{
Organizational Pedagogical Bases for Solution to Preservation Problem of Endangered Minority Languages
}

\author{
Arkady Borisovich Pankin
}

Kalmyk State University, 11 Pushkin Street, Elista, The Republic of Kalmykia, the Russian Federation, 358000

\author{
Doi:10.5901/mjss.2015.v6n4s2p493
}

\section{Abstract}

The article deals with organizational pedagogical bases for solution to preservation problem of minority languages, which are under the threat of disappearance in the implementation process of ethnocultural connotation principle in the content of basic education. The attention is fixed on the delicate status of the Kalmyk language, as a European language of Mongolian origin, on the necessity to protect it effectively in modern conditions. It is substantiated the sequence of integration of ethnic constants - structural elements of central cultural theme of the ethos, as thorough ethnocultural themes in the content of education. The main point of project implementation "Ethnocultural Connotation of Education Content" is presented.

Keywords: minority languages, central theme of ethnos culture, a system of ethnical constants, connotation, ethnocultural connotation of educational content, thorough ethnocultural themes, educational concenters.

\section{Introduction}

A right to use native language is one of the fundamental rights of any nation, of any person, who is entitled to be selfexpressed in his own native language without any limitations. Language rights of national minorities are enshrined in the Resolution of European Parliament [1, 160-164].

In the European Charter Treaty of Regional Languages and Languages of Minorities [2, 148], the notion "languages of minorities" means that languages, which i) are traditionally used in this national territory by the residents of this state, representing a group, numerically smaller than the rest population of the state; and ii) differ from the official language (languages) of this state" (Article 1 item a) of the European Charter Treaty of Regional Languages and Languages of Minorities, dated June 25, 1992).

The Kalmyk language belongs to the languages of national minorities, because, firstly, the Kalmyk language is traditionally used by the residents of the Kalmykia Republic, who, in their turn, represent "a group, numerically smaller, than the rest population of the state"; secondly, the Kalmyk language differs from the official language of the Russian Federation.

The Atlas of World Languages in Danger [3], created by the UNESCO, identifies the Kalmyk as the endangered language to be disappeared from the linguistic map. In the Kalmykia Republic of the Russian Federation, children of Kalmyk nationality, going to school, as a rule, do not speak native language. Consequently, the Kalmyk language is "a language of minorities" and is in danger. That is why, it is especially important to determine the organizational pedagogical bases to solve the problem of preservation of the Kalmyk language, as a language of national minorities, being in danger in the process of ethnocultural connotation [4] of basic educational content.

The attention is paid to the problem solution of preservation of minorities languages, however, in the context of ethnocultural connotation of basic education content, this problem is not considered.

A person views a world through the prism of one ethnic worldview, depending on his needs, plans and possibilities of their implementation. The main idea ethnocultural connotation principle lies in the fact, that according to the concept of "central area of culture", each ethnic culture has a core - a central cultural theme of the ethnos, presenting a system of ethnic constants, an integral part of his ethnical worldview, around which the mobile, variable cultural "periphery" is concentrated. Ethnic constants of each culture are unique and cannot be found in the cultures of other nations, they are universal for all its members, invariable for the ethnos $[5,41]$. The language is a main indicator of personal and ethnic self-consciousness, an important structural element of national culture, the basis for development of its intellect; it is the language, that forms proper ethnic originality [6,27].

The main function of the formation is to pass the ethnocultural experience, recorded in ethnocultural traditions and oriented, firstly, at the reproduction of the universal worldview, at values, ideals, interests, believes, experience and 
standards, fixed in language - the unique value, spiritual and moral property and ethnic constant.

Even if there are doubts relatively psychological pedagogical advantages to be taught in native language, they exist only because for children - representatives of national minorities, the assimilation of "official" language is considered to be more important, than the intellectual and emotional development, socialization and even future of the ethnos itself. Furthermore, the acknowledgement of native languages and the increase of their status by their introduction to the educational system have their own problems. One of the main is the lack of financial, engineering and human resources. School cannot solve this problem itself, but only in cooperation with other social institutes, related and non-related to education [7].

The purpose of education for national minorities is to preserve ethnic constants of central cultural theme of ethnos, to develop the personality in conditions of multilingualism and polyculture, as a bearer of ethnocultural tradition, as a citizen of multinational state.

In modern conditions, the only channel to pass, reproduce and preserve the minority language is the ethnocultural connotation of educational content. A principle of ethnocultural connotation of educational content lies in distinguishing and underlying, preservation and development of structural elements of central theme of ethnos culture, (system of ethnic constants), present in all components of educational system, as a system of measures, providing the formation of relevant ethnic worldview, ethnic way of thinking, developing in a child the assurance in his abilities [8, 90-95]. The content of education is being formed as a thorough ethnocultural theme, systematically present in the training process one-theme content-wise educational material, referring to one of the important spheres of ethnocultural experience, to any ethnic constants, passing through all educational themes.

Thorough ethnocultural themes are introduced in the beginning of education and continue throughout the whole training period, constantly present in the training process, providing the pedagogue with an opportunity to come back repeatedly to thematically homogenous educational material (with different degree of intensity, circulation and according to the principle of concentric growth of difficulties). They pass through the whole course of studies, being determined by the program and make up a core of educational content; they are connected with each other by the relation of succession. An important task is to select, reveal the principles and to determine the recommendations on effective organization of educational content, as a thorough ethnocultural theme on the basis of educational concentrism.

Educational concenters are the "one-theme subjects", all-sufficient volumes of educational material, connected with each other by informative succession (information and volume of the following is bigger and more complex than the preceding), increase and complicating of information, movement from main initially introduced information to more peripheral (foundational information is presented in the beginning, the whole system of knowledge is built on it), up to facultative, conformity of the distributed content with the relevant time intervals.

The features of the notion "educational concenter" are the following: gradation, sequence, ascent from simple to complex, from assimilated to new, circulation (repetition), division of content into definite complexes of qualitatively onetheme information, into "minimums", possessing such peculiarities, as sufficiency, completeness. "Circulation" of one theme at different lessons, thematic inter-subject parallelism provides the student with the opportunity to "dip" for some period of time into definite ethnocultural educational concenter, allowing to form and fix the required knowledge and qualities of child's personality. The teacher systematically comes back to thematically homogenous training material (with different degree of intensity, circulation and based on the principle of concentric growth of difficulties). The educational process presents a movement from concenter to concenter, providing the organization of "thorough ethnocultural theme" [9].

Educational concenters of thorough ethnocultural theme are especially effective at complex consideration of three criteria - linguistic, involving the use of language, as the educational mean; introductory, implemented within the limits of educational reasonability; ethnocultural, presupposing the consideration of importance and priority of information from ethnoculturological positions.

Ethnocultural connotation of educational content promotes the implementation of linguistic safety system for national minorities in the everyday educational practice, and it has the following goals: to transfer children the perception of originality of minority culture, to which they belong, to recover the orientations and content of this culture in them; encouragement of interest to the problems of minorities and children, belonging to the majority group, thus, creating the climate of tolerance and mutual understanding in the group at an early stage of children's development; awakening in adults and teenagers the feeling of faith and devotion to native language and culture, upbringing of dynamic realization of relations between cultures of minorities and majority; provision of access to minority culture to all people, who, speaking another native language, than the minority group, want to get access to it and culture, which it expresses, even if there are only practical reasons for it $[10,22]$.

Educational systems, implementing the principle of ethnocultural connotation, are focused on the provision of full 
basic education in compliance with state standards and bringing children home to native language, culture, history, traditions, moral values; they provide the respect for values of your own culture, as well as the values of other nations, responsibility for preservation and development of native and worldwide cultural tradition.

\section{Literature Review}

The analysis, based on civilized and culturological approaches, allowed establishing the stable blocks in culture and psychology of Kalmyk ethnos - ethnic constants, as structural elements of central cultural theme of the Kalmyk ethnos, the connotation objects of educational content: the Kalmyk language, connected with writing "Clear Writing"; folklore and epos "Jangar"; moral values and spiritual culture; traditional "culture of life support"; historical succession and culture of native land; mongolosphere [11,325], which are the thorough ethnocultural themes and objects of connotation in the content of education of the Republic of Kalmykia.

In the Republic of Kalmykia, in 2014, the ethnocultural theme still present in educational process, but several topic of ethnocultural content are studied during definite, but limited time period. The existing programs of educational subjects, training courses of native language and literature do not take into consideration modern linguistic realties; they are intended to teach children - native speakers. Textbooks, study guides on native language and literature are not reissued or only limited editions are issued, and the newly published ones, even if differ in new approaches, are quite ineffective, as they are prepared outside one concept. Lack of single conceptual constituent makes the authors (the majority of whom are the teachers-practical men, without academic qualification) either to saturate them with insignificant content, or to complicate it; it results in the fact, that for the whole 11-year summer course of Kalmyk language and literature, children cannot learn the native language.

The diversity of approaches result in the appearance of new educational subjects, but their numerosity results in the reduction of hours for studying of other subjects, in their formal passing. Whereas the content of some educational disciplines could be integrated into basic content of education, disclaiming time for the study of another educational subjects.

School in itself cannot provide the succession of culture, if for no other reason, that in this process, it is no more than the mediator, and not the independently acting participator. To solve this problem, the strong support of the community is required, as well as wide joint efforts of schools, mass media, religious and secular institutions, youth camps, economic planning and control bodies; the bodies, providing the political representation of national minorities; the bodies, planning and directing the development of culture, education in places of residence of national minorities [12].

A concept "Ethnocultural Connotation of Educational Content" [13, 216-275] and the Program of its implementation, determined the following as the main purpose: the formation of the field of ethnocultural development of educational content; projecting of content of central ethnocultural theme, thorough ethnocultural themes, to update the programs, teaching materials; the preparation of teaching materials, pedagogical means, implementing the purposes of ethnocultural development, its monitoring; the formation of the teacher-researcher, the author of textbooks, with ethnocultural-connotation content of education; the formation of implementation experience for ethnocultural connotation of educational content.

We developed the organizational-pedagogical bases to preserve the endangered Kalmyk language: the development and adoption of the Law of the Kalmykia Republic "About the Endangered Kalmyk Language" (The Law is aimed at the provision of preservation and use of the Kalmyk language in the whole territory of the Republic of Kalmykia, at the enforcement of citizens' right to use the Kalmyk language, at the preservation and protection of the Kalmyk linguistic culture, at preservation of succession of historical traditions of Kalmyk writing); the development and adoption of the endangered Kalmyk language development concept; the development and adoption of the State Program of the Kalmykia Republic "Preservation of the Kalmyk Language for the Period from 2015 to 2025"; the plan of implementation of the State Program of the Kalmykia Republic "Preservation of the Kalmyk Language for the Period from 2015 to 2025"; the development and adoption of the concept of regional educational content: preparation and issuing of the academic work "The Kalmyk Language", the organization of the commission on terminology, orthography and toponyms', determination of lexical minimum of content of the educational subject "The Kalmyk Language and Literature", the development and issuing of new generation of textbooks "The Kalmyk Language and Literature", the development of testing system on Kalmyk language for the system of continuous education, the training of textbook authors on the subject "The Kalmyk Language and Literature", the organization of system of continuous linguistic education for the Kalmyk language teachers, the development and implementation of modern Kalmyk language educational technologies, the organization of retraining system for the Kalmyk language teachers, the organization of the support system for the Kalmyk language in the territory of the Kalmykia Republic; the creation of testing sites on program implementation of the 
educational subject "The Kalmyk Language and Literature".

In order to implement the concept "Ethnocultural Connotation of the Educational Content", a Social Councils on the Kalmyk language development were created under the head of the Kalmykia Republic, a non-commercial fund "Khalmg Keln" ("The Kalmyk Language") was opened under the heads of regional and municipal entities, a project "Ethnocultural Connotation of the Educational Content" was considered and approved in the Kalmyk State University, to implement which, the research and educational center "Bagsh" ("Teacher"), named after the academician G.N. Volkov, was created.

The main directions to implement the organizational pedagogical bases of activity determine the formation of academic partnership "school - university - scientific center - mass media" with educational institutions of the Department of Education and Science of the Kalmykia Republic, the Kalmyk Institute of Humanitarian Research of the Russian Academy of Science and Television Broadcaster "Syan Tsag" ("New Time"); the provision of safety functioning of the Kalmyk language; the formation of new generation of teachers-researchers; the training of the top-qualified pedagogues (Doctors of Philosophy and Doctors of Science); the preparation and issuing of system of stable products for the educational process: monographs, programs, study guides and textbooks with ethnocultural content of education (based on connotation of ethnic constants into educational content, as thorough ethnocultural themes), based on state educational standards; the shift of educational institutions of the Kalmykia Republic to the work as per the program of educational subject "The Kalmyk Language and Literature"; the preparation and holding of scientific pedagogical conferences on the problems of preservation of the endangered Kalmyk language.

The stages of formation of the ethnocultural educational content are the following: the postgraduates, following the suggested topics, the content of which is closely connected with the analysis of ethnic constants, as thorough ethnocultural themes, studied at definite educational levels, are involved into thesis research, the results of which get the qualification assessment; based on the thesis, the monographs are published; the thesis and monographs, according to the education plan, become the basis of study guides, books, reading books and educational materials for relevant classes of different educational levels; the authors of study guides are joined into creative teams, create the textbooks with ethnocultural connotation content of education for the relevant educational subjects of different educational levels. Ethnic constatns of central cultural theme of the ethnos are connotated into programs, textbooks, study guides, books, reading books and other materials.

At that, it is assumed the following: the interaction on the problems of determination of prospective teachers future postgraduates; the organization and holding of scientific pedagogical seminars in the regions of the Kalmykia Republic; the exchange of educational and other video production with the television broadcasters of Mongolia, Buryatia, China and other countries; the preparation of teaching-methodological materials for educational institutions of the Kalmykia Republic; the holding of mutual scientific research in the sphere of pedagogics, experimental and other works on vital directions, presenting mutual interest; the implementation of scientific- research and scientific - methodological works under the implementation of the project "Ethnocultural Connotation of Educational Content".

Thus, in modern conditions, the only principle, providing the preservation of minority languages, is a principle of ethnocultural connotation of the educational content, the implementation of which is possible, if the definite organizational-pedagogical conditions are made. Education becomes the way to reproduce the universal ethnic worldview and to develop its constituents - structural elements of central theme of ethnos culture - a system of ethnic constants through their systematic use in everyday pedagogical practice, by means of ethnocultural connotation of the educational content.

\section{References}

Resolution on the languages and cultures of regional and ethnic minorities in the European Community (The Kuijpers Resolution), 1987. Official Journals of the European Communities. NC, pp: 318.

European Charter for Regional or Minority Languages, 1992. Strasbourg. European Treaty Series, pp: 148.

Mozly C., 2010. The Atlas of Word Endangered Languages. Issue 3, Paris: Published by UNESCO, www. unesco.org/culture/en/ endangeredlanguages/atlas.

Oxford Dictionaries. Language Matters, www. oxford dictionaries. com/definition/english/connotation.

Shils, E., 1961. Centre and Periphery. The Logic of Personal Knowledge: Essays. London: Routledge \& Kegan Paul, pp: 39-84.

Fishman, J.A., 1952. Language and Nationalism. Rowley, Mass, The Cultural Background of Personality.

Fishman, J.A., 1984. Epilogue: The Rise and Fall of the Ethnic Revival in the USA.

Pankin, A.B., 2012. Ethnocultural Connotation of the Content of Education in the Conditions of Implementation of the Concept of Stabilizing Modernization. The Bulletin of the Adyghe State University. Series "Pedagogy and Psychology", Maikop: Publishing House «Adyghe State University», Issue 3, pp: 206.

Vorobyov, V.V., 1997. Lingvoculturology (Theory and Methods). M., pp: 334. 
Khruslov, G.V., 1994. Resolution on Languages and Cultures of Regional and Ethnic Minorities in European Community (Resolution of Kuijpers). The Linguistic Rights of Ethnic Minorities in the Sphere of Education: Coll. of Materials, M.: INPO, pp: 20-35.

Pankin, A.B., 2009. Ethnocultural Connotation of Education: a Monograph. Elista: The Kalmyk University Publishing House, pp: 380.

Fishman, J.A., 1984. The Rise and Fall of the Ethnic Revival: Perspectives on Language and Ethnicity. Berlin.

Pankin, A.B., 2002. Projecting of national regional educational systems based on the principle of ethnocultural connotation. PhD thesis, Volgograd: VGPU. 